\title{
Septic Pulmonary Embolism
}

\author{
Gamze Çelik Türnüklü, Coşkun Doğan, Sevda Şener Cömert, \\ Benan Çağlayan, Ali Fidan, Elif Torun Parmaksız, Banu Salepçi
}

\footnotetext{
Department of Chest Diseases, Kartal Dr. Lütfi Kırdar Training and Research Hospital, İstanbul, Turkey

Submitted: 19.11.2015 Accepted: 04.04.2016

Correspondence: Gamze Çelik Türnüklü, Şemsi Denizer Cad.

E-5 Karayolu Cevizli Mevkii, 34890 Kartal, İstanbul, Turkey E-mail: dr.gamzecelik@hotmail.com

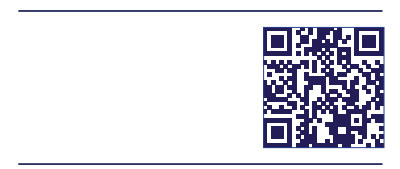

Keywords: Pulmonary embolism; septic pulmonary embolism.
}

\begin{abstract}
Septic pulmonary embolism (SPE) is an infective pulmonary disease that develops secondary to any source of infection and presents with signs and symptoms such as pulmonary infiltrates, fever, chest pain, and cough. SPE can be defined as a thrombus containing microorganisms embedded in fibrin that moves from an infectious focus and settles in pulmonary arteries. It usually causes multiple or bilateral nodular, cavitary, or wedge-shaped infiltrates, usually settled in the peripheral and neighborhood vessels of lung parenchyma. A patient diagnosed with SPE is presented as a case study in the literature since it is a rare condition.
\end{abstract}

\section{INTRODUCTION}

Septic pulmonary embolism (SPE) is a rare condition that occurs in the lungs in the presence of a primary focus of infection such as oropharyngeal region infections, central venous catheter thrombophlebitis, right heart endocarditis, and intravenous (IV) drug usage. The microorganism containing fibrins that are sourced from the primary focus of infection get into circulation and cause obstructions in the pulmonary arteries by forming nodular or cavitary lesions at the end of vessels in the lung parenchyma. These conditions are the main pathogeneses of this disease. It is usually presented with some nonspecific symptoms like fever, hemoptysis, cough, chest pain, and some bilateral multiple-localized nodules, and/or cavities in the peripheral and neighborhood vascular regions, radiologically. As lesions settle at the end of vessels, a view called "feeder vessel symptom" is formed in the lung parenchyma. ${ }^{[1-5]}$

Computed tomography $(\mathrm{CT})$ is a better imaging technique compared with chest radiography for visualizing lesions, and detecting the feeder vessel symptom, relationship between the pleural cavity and the lesions, and finally severity and possible complications of the disease. The diagnosis and the treatment of SPE are hard. To be able to make a correct diagnosis, another important factor is the determination of the infection source. The most important factors that determine the prognosis of the disease are early diagnosis and early treatment with broad-spectrum antibiotics. ${ }^{[5-7]}$

In this study, an SPE case with a dialysis catheter was presented.

\section{CASE REPORT}

A 52-year-old female admitted to the hospital because of chest pain, cough, phlegm, and fever. Her posterior-anterior chest radiography ( $\mathrm{X}$-ray) revealed increases in bilateral, dispersed nodular opacities (Figure I). Her medical history revealed several serious diagnoses like coronary artery disease, chronic kidney failure (CKF), and hypertension (HT). She had been taking hemodialysis (HD) treatment three times a week. She did not have any genetic 
history. She had a 10 pack-year history of smoking. Her physical examination showed that her medical state was fair; she was conscious, co-operative, and well oriented. The right middle area revealed inspiratory rales. The fever was $38.1^{\circ} \mathrm{C}$; the tone was $108 / \mathrm{min}$, blood pressure was $130 / 70 \mathrm{~mm} \mathrm{Hg}$, and number of breaths per minute was 25 . The oxygen saturation at the room temperature was 92 . Other system examinations did not show any pathological feature.

Her laboratory results were as follows: hemoglobin, $9.5 \mathrm{~g} /$ $\mathrm{dL}$; hematocrit, 28.3; leukocyte, $43,000 / \mu \mathrm{L}$; sedimentation, III/hour; serum C-reactive protein (CRP), 403 mg/dL; pro-calcitonin, $72 \mathrm{ng} / \mathrm{mL}$; international normalized ratio, I.58; urea, $121 \mathrm{mg} / \mathrm{dL}$; and creatinine, $8.1 \mathrm{mg} / \mathrm{dL}$. Increases in many bilateral nodular densities (in different sizes) were observed in the thoracic CT sections of the case. In some of them, the feeder vessel syndrome was seen (Figure 2).

Since the case had lung infection findings, high infectious parameters in her laboratory tests, and also had a permanent HD catheter, SPE was considered in the definitive diagnosis, first. Two peripheral blood samples and phlegm samples were taken from the patient. The treatment started, after taking the opinion from the infectious disease clinic, empirically by giving meropenem $500 \mathrm{mg}$ (IV) IxI, linezolid 600 $\mathrm{mg}$ (IV) $2 x \mathrm{l}$, and moxifloxacin $400 \mathrm{mg}$ (IV) IxI.

Transesophageal echocardiography (TEE) was done to find the source of the extrapulmonary infection. It was reported that as a catheter was followed from superior vena cava (VCS) to the right atrium, a I-cm motile bulk image was observed in the exit of the VCS on the catheter. Additionally, an advanced tricuspid failure, a secondary aorta failure, and a moderate mitral failure were reported.

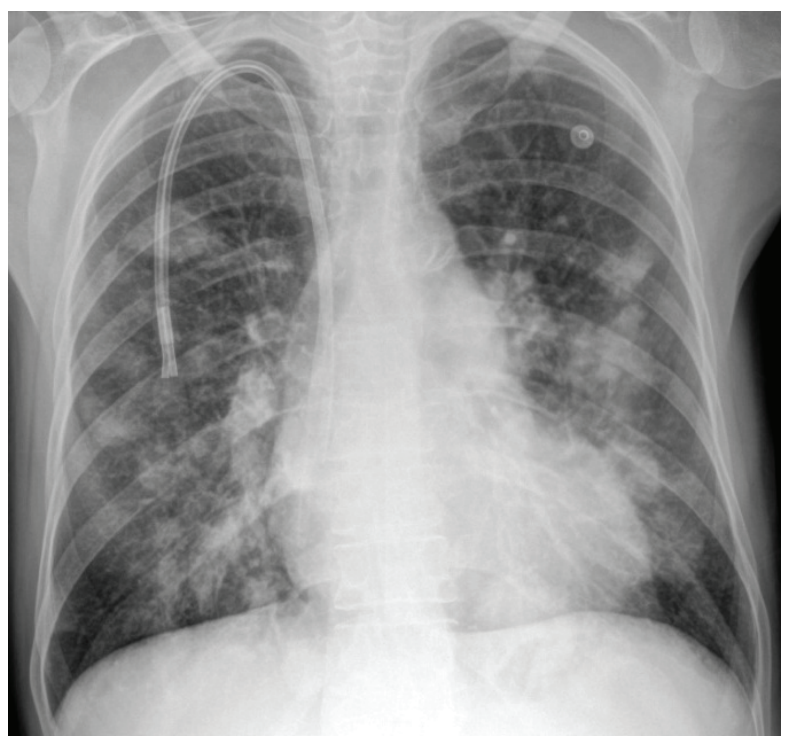

Figure 1. Increases in bilateral, dispersed nodular opacities were observed in the posterior-anterior chest radiography.
No germs grew in the phlegm culture; however, Staphylococcus hominis grew in the blood culture. Her antibiogram revealed that the patient was sensitive to the treatments that she took. For this reason, her treatment was not changed. In the second day of the triple antibiotic treatment, patient's fever reduced and her clinical symptoms became significantly better. It was seen that the size of the lesions in the control radiography, which were taken in the first and second weeks of the hospitalization, became smaller (Figure 3 ). In the end of the 14-day treatment, the following results were obtained: leukocyte, $8600 / \mu \mathrm{L}$; CRP, I3 $\mathrm{mg} / \mathrm{dL}$; pro-calcitonin, I. $18 \mathrm{ng} / \mathrm{mL}$; and sedimentation: 84/ hours. The lesions were found to be almost disappeared in the thoracic CT after 2 months (Figure 4). Consent was obtained from the patient who participated in this study.

\section{DISCUSSION}

This case was presented to remark the diagnosis and treatment of SPE, which is a rare infectious disease but oc-
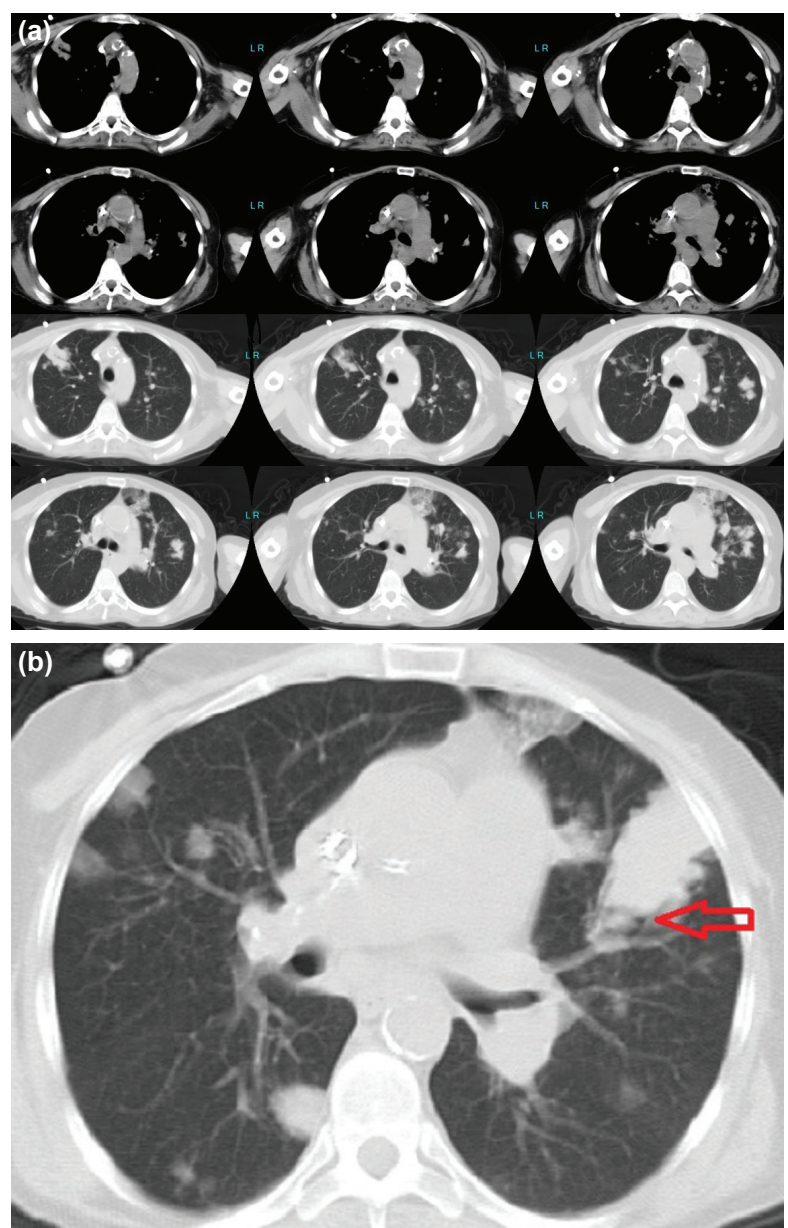

Figure 2. (a) Increases in many bilateral nodular densities (in different sizes) were observed in the thoracic computed tomography (CT) sections of the case. (b) Feeder vessel symptom was seen in some of the thoracic CT sections of the case (labeled with a red arrow). 


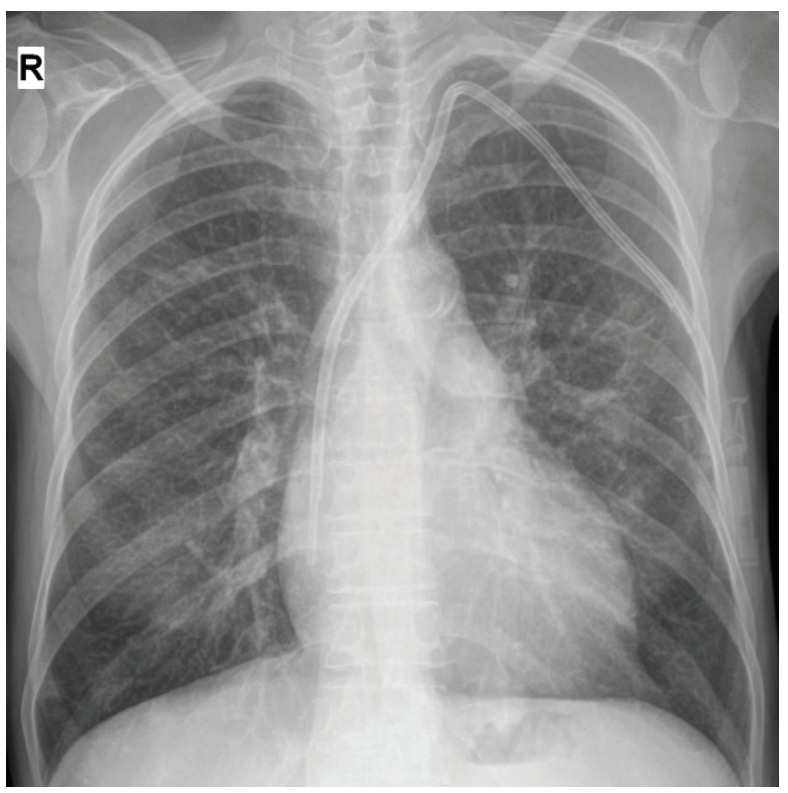

Figure 3. Size of the lesions in the control radiography, which were taken in the first and second week of the hospitalization, became smaller.

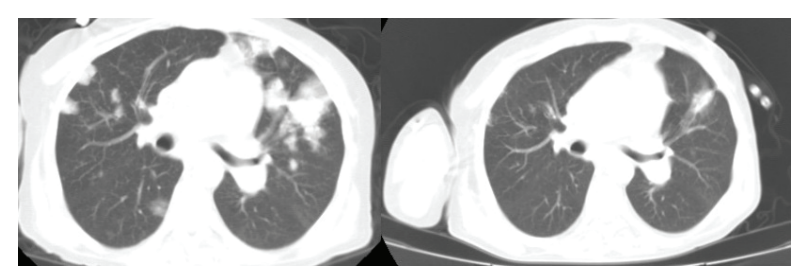

Figure 4. Lesions almost disappeared in the thorax computed tomography after 2 months.

curs with a severe prognosis. In addition, if SPE is not kept in mind in the definitive diagnosis, the clinician may have difficulty in diagnosing this disease. And if early antibiotic treatment is not applied, the mortality rate of SPE becomes higher.

SPE is a rare clinical condition. However, it occurs with a serious prognosis. Studies showed that SPE occurs as an inflammatory disease and manifests with bilateral infiltrations in the lung and a focus of extrapulmonary infection. Por Wen Yang et al., in their study, analyzed 28 cases with SPE whose average age was 44, and they reported that the age of incidence scatters over a wide range. ${ }^{[8]}$ In this study, the time from the beginning of symptoms to diagnosis was reported as II days. Several studies showed that a high fever is the most common symptom besides cough, dyspnea, pleuritic pain, hemoptysis, fatigue, throat ache, myalgia. IV drug usage, tricuspid lid endocarditis, end-stage kidney failure, chronic liver diseases, diabetes mellitus, and alcoholism, and immune deficiencies like HIV infection can be given as predisposing factors of SPE. ${ }^{[8,9]}$ The case in this study was a 52-year-old female, and she had a cough, chest pain, shortness of breath, and high fever. Especially, the chest pain that started suddenly with a high fever and increased with breathing caused a noisy clinic. In 2005, Cook et al. conducted a study with 14 patients, and their results showed that the focuses of infection were Lemiere syndrome (29\%) and central catheter infection (21\%); the predisposing factors were given as infected pacemaker, dental apse, perinephric apse, and prosthetic pulmonary lid endocarditis. ${ }^{[3]}$ Since the patient in this study had several risk factors, such as CKF and a permanent catheter, her clinical condition raised suspicion in terms of SPE, and her infected catheter was shown with TEE.

Goswami et al., in this study, evaluated 40 SPE patients, and they found that $63 \%$ of the radiographic features occurred in the first 72 hours of the disease. No clear lesion was seen in the first chest radiography in furtherance of
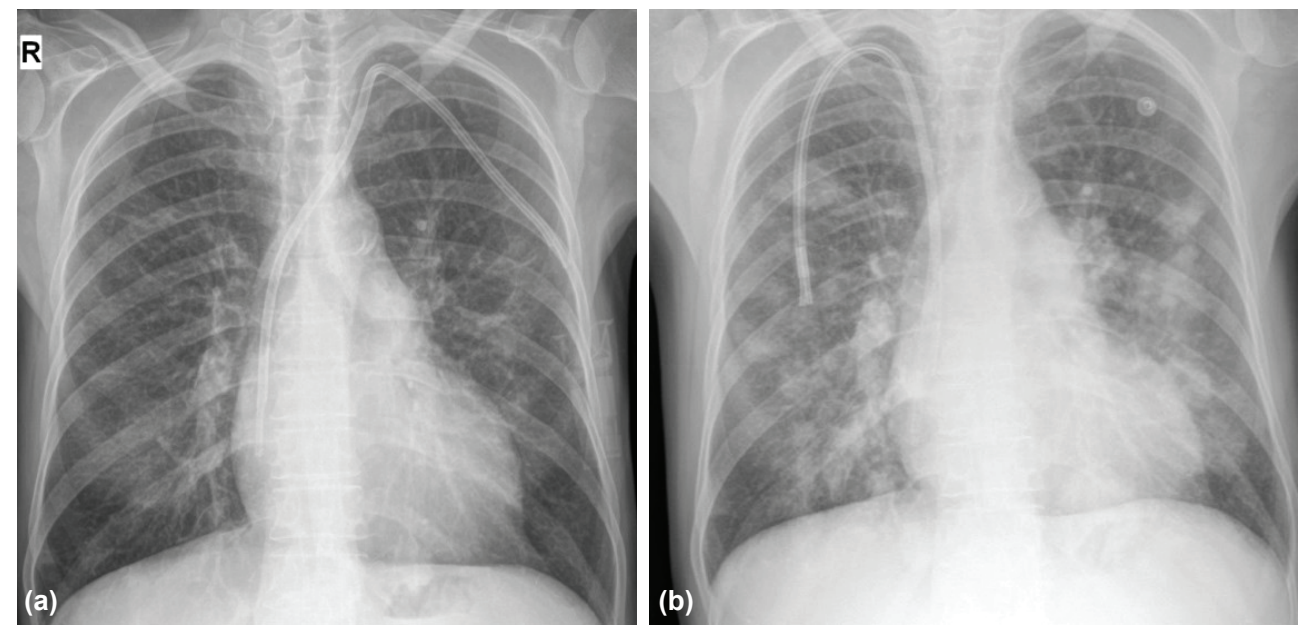

Figure 5. (a) Chest radiography that was taken 1 day before the admission to the clinic of pulmonary diseases: A suspicious infiltration in the left middle zone and right bottom zone. (b) Chest radiography that was taken at the day of admission to the clinic of pulmonary diseases: Infiltrations in the left middle zone and right bottom zone became evident, newly formed nodular lesions in the bilateral middle bottom zones. 
this study. However, increases in significant bilateral dispersed nodular opacities were observed in the second radiography, which was taken only I day after the first radiography because of the increased complaint of the patient. This situation was also thought of as the sign of the fast prognosis of SPE, if it was not diagnosed or treated earlier (Figure 5a, b). CT is an important diagnostic tool among radiological imaging techniques, and it allows to see bilateral, infiltrative, nodular, cavitary lesions. According to studies on SPE, the "feeder vessel symptom" is usually seen in $60 \%-70 \%$ of patients. In addition, lesions in the form of sub-pleural wedge is an important indicator of SPE, and they are seen in $70 \%-75 \%$ of patients. The thoracic $C T$ sections of the patient in the current study revealed many peripheral-localized nodular lesions of different sizes; however, no cavitation was formed. In a study that was performed to analyze radiological images of patients who were diagnosed with SPE, bilateral nodular lesions that included feeder vessel symptoms were observed in $67 \%$ of patients. In the same study, sub-pleural wedge-like lesions and pleural fluid were seen in $73 \%$ and $67 \%$ of patients, respectively. ${ }^{[9,10]}$

Staphylococcus infections are the most common factors that have been reported so far. A growth of Staphylococcus was also detected in the blood sample of the patient in this study. ${ }^{\left[{ }^{11}\right]}$ Even though antibiotic treatment usually gives a positive treatment response, surgical intervention may be needed depending on the focus of infection. Some of these infections are tricuspid lid replacement, liver apse-specific drainage, and fasciotomy in the case of soft tissue infection. In this case, the displacement of the infected catheter can be counted as one of these factors.

Consequently, SPE is a rare clinical condition. Early clinical suspicion and thoracic CT were enough for the diagnosis. SPE needs to be considered in the case of having a high fever and high infectious parameters, such as CRP and sedimentation values, in the presence of bilateral, multiple, and peripheral-localized nodules at the vessel ends in the lung of the thoracic CT images of patients having a secondary focus of infection and also having a feeder vessel symptom. In these clinical conditions, early antibiotic treatment should be started.

Authorship contributions

Concept: C.D.; Design: C.D.; Data collection \&/or processing: E.T.P.; Analysis and/or interpretation: A.F.; Literature search: S.C., B.S.; Writing: G.Ç.T.; Critical review: B.Ç.

Conflict of interest

None declared.

\section{REFERENCES}

1. Özlü T, Metintaş M, Karadağ M, Kaya A. In: Akın K, editor. Solunum sistemi ve hastalıkları. 1st ed. İstanbul: İstanbul Tip Kitabevi; 2010. pp. 1219-24.

2. Doğan C, Şener SŞ, Kıral N, Torun E, Salepçi B, Çağlayan B. Septic Pulmonary Embolism Secondary to Both Extraction. J Kartal TR 2011;22:79-83. [CrossRef]

3. Cook RJ, Ashton RW, Aughenbaugh GL, Ryu JH. Septic pulmonary embolism: presenting features and clinical course of 14 patients. Chest. 2005;128:162-6. [CrossRef]

4. Wong KS, Lin TY, Huang YC, Hsia SH, Yang PH, Chu SM. Clinical and radiographic spectrum of septic pulmonary embolism. Arch Dis Child 2002;87:312-5. [CrossRef]

5. Rossi SE, Goodman PC, Franquet T. Nonthrombotic pulmonary emboli. AJR Am J Roentgenol 2000;174:1499-508. [CrossRef]

6. Akpınar S, Uçar N, Öztürk S, Şerifoğlu İ, Yıldız M, Şipit TA Case of Septic Pulmonary Embolism. CausaPedia 2014;3:559.

7. Christensen PJ, Kutty K, Adlam RT, Taft TA, Kampschroer BH. Septic pulmonary embolism due to periodontal disease. Chest 1993;104:1927-9. [CrossRef]

8. Yang PW, Lin KH, Chen JD, Tiu CM, Lin HD. Septic Pulmonary Embolism: Analysis of Twenty-Eight Cases. J Intern Med Taiwan 2013;24:1-7.

9. Goswami U, Brenes JA, Punjabi GV, LeClaire MM, Williams DN. Associations and outcomes of septic pulmonary embolism. Open Respir Med J 2014;8:28-33. [CrossRef]

10. Huang RM, Naidich DP, Lubat E, Schinella R, Garay SM, McCauley DI. Septic pulmonary emboli: CT-radiographic correlation. AJR Am J Roentgenol 1989;153:41-5. [CrossRef]

11. Brenes JA, Goswami U, Williams DN. The association of septic thrombophlebitis with septic pulmonary embolism in adults. Open Respir Med J 2012;6:14-9. [CrossRef]

\section{Septik Pulmoner Emboli}

Septik pulmoner emboli (SPE) herhangi bir enfeksiyon odağına ikincil olarak gelişen akciğer infiltrasyonları, ateş, göğüs ağrısı, öksürük gibi bulgular ile prezente olan enfektif bir akciğer hastalığıdır. Enfeksiyon odağından hareket eden fibrin içine yerleşmiş mikroorganizmaları içeren bir trombus pulmoner arterlere yerleşir ve iki taraflı akciğer parankiminde genellikle periferik ve damar komşuluğunda yerleşen genellikle multipl ve iki taraflı nodüler, kaviter veya kama şeklinde infiltrasyonlara yol açar. Bu yazıda, SPE tanısı alan bir olgu nadir görüldüğü için literatür eşliğinde sunuldu.

Anahtar Sözcükler: Pulmoner emboli; septik pulmoner emboli. 